\title{
Aerial Applications of Ethylene-Releasing Chemicals Fail to Promote Abscission of Dwarf Mistletoe Aerial Shoots on Jack Pine ${ }^{1}$
}

by

\author{
F.A. Baker ${ }^{2}$, K. Knowles ${ }^{3}$, T.R. Meyer $^{4}$, and D.W. French ${ }^{5}$
}

\begin{abstract}
The ethylene-releasing chemical Cerone ${ }^{6}$ was applied in early August to two strands of jack pine infested with the lodgepole pine dwarf mistletoe in northwestern Manitoba. Nine weeks after aerial application, Cerone failed to cause appreciable abscission of dwarf mistletoe aerial shoots, while almost $90 \%$ of the aerial shoots on branches treated from the ground had abscised. Ground application of Cerone could reduce spread of dwarf mistletoe by limiting seed production.
\end{abstract}

Key Words: Arceuthobium, jack pine, chemical control

\section{Résumé}

Un agent émetteur d'éthylène, le ceron 6 , a été dispersé en début d'août sur deux peuplements de pin gris infestés par le faux gui du pin tordu dans le nordouest du Manitoba. Neuf semaines après les arrosages aériens, le cerone n'a pu provoquer l'abscission notable des pousses aériennes du faux gui, tandis que $90 \%$ des pousses aériennes situées sur les branches traitées à partir du sol étaient abscissées. L'application de ceron à partir du sol pourrait réduire l'étendu du faux gui en limitant sa production de semences.

Mots clés: Arceuthobium, contrôle chimique, pin gris.

\section{Introduction}

Dwarf mistletoes (Arceuthobium spp.) are the most damaging parasites of conifers in the western United States and Canada. The lodgepole pine dwarf mistletoe, A. americanum Nutt. ex. Englem., causes the largest annual loss in merchantable lodgepole (Pinus contorta Dougl.) and jack pines ( $P$. banksiana Lamb.) in the Prairie Provinces of Canada (Hiratsuka 1987). The parasite is particularly damaging when large numbers of infections become established early in the life of the stand. In such stands, a commercial harvest may be impossible because of losses caused by dwarf mistletoe. Recent studies demonstrated that rapidly growing trees can outgrow the upward spread of some dwarf mistletoes, limiting infections to the lower crown where damage from the pest will no longer be a problem (Scharpf and Parmeter 1976, Roth and Barrett 1985). Growth of severely infested young jack pine stands could be maintained by encouraging tree growth and limiting disease spread by removing the most severely infected trees and pruning infected branches. Pruning, however, is expensive and stands must be retreated to keep the dwarf mistletoe population at a low level. Any method that reduces subsequent seed dispersal and intensification of the parasite while the trees grow in height could eliminate the need for, or greatly extend the interval between retreatments.

\footnotetext{
This paper is published with the approval of the Director, Utah Agricultural Experiment Station, Utah State University, Logan, UT, USA, as Journal Paper No. 3452.

${ }^{2}$ Department of Forest Resources, Utah State University, Logan, UT 84322-5215;

${ }^{3}$ Forest Protection, Forestry Branch, Manitoba Natural Resources, Winnipeg, Manitoba R3N 1 Z4.

${ }^{4}$ Department of Botany, University of Manitoba, Winnipeg, Manitoba R3T 2N2

${ }^{5}$ Department of Plant Pathology. University of Minnesota, St. Paul, MN, USA 55108

${ }^{6}$ The use of trade names does not imply endorsement by the authors or their institutions nor does it constitute criticism of similar products not mentioned.

L'utilisation de marques de commerce n'implique pas une approbation de la part des auteurs ou de leur organisation, ni ne constitue une critique des produits semblables non mentionnés.
}

Attempted chemical controls for dwarf mistletoes have not killed the dwarf mistletoe without seriously injuring the host (Lightle and Lampi 1973, Quick 1964). Ground applications of ethylene-releasing agents have recently been found effective in stimulating abscission of dwarf mistletoe aerial shoots when applied prior to seed dispersal, thus eliminating the seeds available for dispersal (Livingston and Brenner 1983, Livingston et al. 1985, Robbins et al. 1989). The parasite still persists in the tree, and a new crop of aerial shoots will emerge the year after treatment, producing seed one or two years later.

Areas of dwarf mistletoe infection are extensive in Manitoba and other regions. As a consequence, practical methods for control of dwarf mistletoe on large areas need evaluation. This study was done to compare the effectiveness of aerial and ground applications of Cerone (Union Carbide Corporation), an ethylene-releasing agent, in causing abscission of aerial shoots of $A$. americanum on jack pine.

\section{Methods}

Two jack pine stands infested with dwarf mistletoe were selected in northwestern Manitoba approximately $110 \mathrm{~km}$ east of The Pas. At the first stand, three plots were established in a 5-ha spray block treated with Cerone and three plots were established outside the spray block. On each plot, pistillate dwarf mistletoe shoots were counted on 30 branches from witches' broom type infections. Three plots were established on the second study area, one in another 5-ha spray block treated with an aerial application, one plot treated with a ground application, and one plot left untreated. Pistillate dwarf mistletoe shoots on 50 branches were counted on the aerial application plot and the untreated plot, and on 30 branches on the ground application plot. Dwarf mistletoe 
shoots counted on branches in the second study area were primarily on swelling type infections. Pre-treatment dwarf mistletoe shoot counts were made in the third week of July 1986.

Cerone at $2400 \mathrm{ppm}$ ethephon, $1101 / \mathrm{ha}$ (280 g active ingredient/ha) amended with a surfactant (0.1\% NU-FILM 17) and a buffer (0.1\% SPRAY-AID) was applied on 1 August 1986 by a Grumman Ag Truck flying within $15 \mathrm{~m}$ of the crown canopy. Applications were made between 0900 and 1030 CDST, when the air temperature was $18 \mathrm{C}$ and winds were $13-16 \mathrm{kph}$ with light gusts. The ground application with the same formulations and concentration was made on 29 July 1986 using a backpack mistblower. Treatment effectiveness was evaluated by comparing counts of dwarf mistletoe shoots before and nine weeks after treatment.

\section{Results and Discussion}

Table 1 shows the change in the population of pistillate dwarf mistletoe shoots. The increase of dwarf mistletoe shoots on untreated plots represents error in counting, and/or, more likely, emergence of new aerial shoots during the period between initial and final counts. The ground application reduced the population of pistillate dwarf mistletoe shoots by almost $90 \%$. The aerial treatments may have caused some abscission of dwarf mistletoe shoots on treated branches, but that effect was unimportant from a disease management standpoint. Had the treatment been effective, we would expect a reduction in the population of pistillate dwarf mistletoe shoots similar to that observed in the ground treatment, rather than the increase observed. Other studies have also found aerial applications ineffective in causing abscission of dwarf mistletoe aerial shoots (Robbins et al. 1989). The application was made at what was considered the maximum feasible volume and concentration of Cerone. Even so, the spray apparently did not penetrate the foliage and reach the

Table 1. Change in population of pistillate dwarf mistletoe shoots on jack pine branches nine weeks after aerial and ground application of Cerone.

\begin{tabular}{lcc}
\hline Treatment & Study & $\begin{array}{c}\text { Change in aerial } \\
\text { shoot } \\
\text { population } \\
(\%)\end{array}$ \\
\hline Type & area & +20 \\
Aerial treatment & 1 & +53 \\
Untreated & 1 & +2 \\
Aerial treatment & 2 & +33 \\
Untreated & 2 & -89 \\
Ground application & 2 & \\
\hline
\end{tabular}

aerial shoots in concentrations great enough to promote abscission. The ground application, which was made until chemical ran off the branches, provided sufficient coverage and chemical to cause abscission of aerial shoots.

Although treatments with ethylene-releasing chemicals do not kill the endophytic system of the dwarf mistletoe and the parasite can produce new shoots, such treatments may be useful in situations where a ground application can be made to greatly reduce seed dispersal. Along the southeast shores of Lake Winnipeg, many summer home developments are located in severely infested jack pine stands, where other species are of minor importance. A sample of 100 trees in one development revealed that 95 were infested and 60 were declining. In just five years, 48 trees have died, and the others will die unless the parasite is controlled. Combined with pruning, ethylene-releasing chemicals could reduce dwarf mistletoe seed production in existing infected trees, allowing jack pines replanted on the site to develop free of the parasite. Pruning and ethylene-releasing chemicals could also be used to prevent further intensification of the parasite and prolong the life of valuable ornamental trees.

\section{Acknowledgements}

We gratefully acknowledge the contributions of Larry Matwee and the operations staff, Forestry Branch, Manitoba Natural Resources, and Bruce Milligan, Union Carbide-Ag Products Canada.

\section{References}

Hiratsuka, Y. 1987. Forest tree diseases of the Prairie Provinces. Can. For. Serv. Nor. For. Centre Info. Rep. NOR-X-286. 142p.

Lightle, P.C. and E.H. Lampi. 1973. Herbicides ineffective in controlling southwestern dwarf mistletoe. USDA For. Serv. Rocky Mountain For. and Range Exp. Stn. Res. Note RM 242, 3p.

Livingston, W.H. and M.L. Brenner. 1983. Ethephon stimulates abscission of eastern dwarf mistletoe aerial shoots on black spruce. Plant Disease 67: 909-910.

Livingston, W.H., R.A. Blanchette, M.L. Brenner and K.J. Zuzek. 1985. Effective use of ethylene-releasing agents to prevent spread of eastern dwarf mistletoe on black spruce. Can. J. For. Res. 15: $872-876$.

Quick, C.R. 1964. Experimental herbicidal control of dwarfmistletoe on some California conifers. USDA For. Serv. Southwest For. and Range Exp. Stn. Res. Note PSW-47. 9p.

Robbins, K., D.W. Johnson, F.G. Hawksworth and T.H. Nicholls. 1989. Aerial application of ethephon is ineffective for controlling lodgepole pine dwarf mistletoe. Western J. Appl. For. (4:27-28)

Roth, L.F. and J.W. Barrett. 1985. Response of dwarf mistletoeinfested ponderosa pine to thinning: 2. Dwarf mistletoe propagation. USDA For. Serv. Pac. Northwest For. and Range Exp. Stn. Res. Pap. PNW-331. 20p.

Scharpf, R.F. and J.R. Parmeter, Jr. 1976. Population buildup and vertical spread of dwarf mistletoe on young red and white firs in California. USDA For. Serv. Pac. Southwest For. and Range Exp. Stn. Res. Pap. 125W-122. 9p.

\section{La forêt: des richesses pour tous}

